\title{
Invited review: Carryover effects of early lactation feeding on total lactation performance in dairy cows
}

\author{
C. H. Jørgensen, ${ }^{* 1}$ R. Spörndly, $†$ J. Bertilsson, $†$ and S. Østergaard* \\ *Department of Animal Science, Aarhus University, DK-8830 Tjele, Denmark \\ †Department of Animal Nutrition and Management, Swedish University of Agricultural Sciences, SE-753 23 Uppsala, Sweden
}

\begin{abstract}
In comparison with the intensive research on the direct effects of energy supply on dairy cow lactation performance, little attention has been paid to the effect of early lactation feeding on subsequent production. The present paper reviews 9 studies carried out with the aim of quantifying the immediate and subsequent responses in milk production and body weight to early lactation feeding. Most results showed that a more generous feeding in early lactation caused a positive carryover effect on subsequent production, whereas an inadequate level of feed in early lactation has been shown to reduce subsequent milk yield. The carryover periods ranged from 3 to $12 \mathrm{wk}$ and the difference in milk yield between cows in the carryover periods ranged between 1.5 and $4.5 \mathrm{~kg}$ of milk/cow per day. When calculated as a percentage of the immediate effect, the carryover effect ranged from 22 to $63 \%$. In 2 of the 9 papers reviewed, the authors found no carryover effect, probably due to the long post-treatment periods in these studies. This is supported by the other studies in which the carryover effect was only significant in a limited period after end of treatment. The magnitude of the carryover effect seems to be determined by several factors including duration of the treatment and post-treatment feeding level. The most important factor though appears to be the magnitude of over- or underfeeding (i.e., a strong relationship between the treatment period feeding level and the subsequent response in production).
\end{abstract}

Key words: dairy cow, feeding level, milk yield, carryover effect

\section{INTRODUCTION}

Traditionally recommendations for feeding dairy cows in early lactation have been based on standard need of energy and protein for maintenance, growth,

Received October 30, 2014.

Accepted December 6, 2015.

${ }^{1}$ Corresponding author: carina.jorgensen@agrsci.dk and milk production. The optimal feeding on the farm level seen from an economic point of view should, however, be estimated with respect to feed and milk prices. As prices may vary considerably over time (FAO, 2012), it could be argued that the feeding level of the dairy cows should be adjusted according to price changes during the lactation. Economic optimization within herds requires an accurate prediction of the marginal production responses to changes in nutrient supply. The evidence on immediate effects of feeding on production has been variously reviewed (e.g., Wiktorsson, 1971; Coulon and Rémond, 1991; Broster et al., 1993). However, research indicates that changes in feeding level during the lactation not only have an immediate effect on production, but that level of nutrition during the first few weeks of lactation can have a major effect on subsequent lactation performance. As early as 1950 (cited in Broster and Broster, 1984), attention was drawn to the possibility that previous feeding could affect current production. Since then, numerous studies have investigated the carryover effect of energy and protein level on milk production and BW changes.

In a review, Sejrsen and Purup (1997) described the effect of prepubertal feeding on milk yield potential in dairy heifers. Also, the effect of feeding level during the dry period on subsequent lactation performance has been demonstrated in different studies (Holter et al., 1990; Holcomb et al., 2001). Other studies have focused on the carryover effects of feeding in one lactation on production and body condition in the subsequent lactation, as reviewed by Broster et al. (1993).

In a comprehensive review, Broster and Broster (1984) studied the effects of feeding level on production in dairy cows in literature through about $30 \mathrm{yr}$. The conclusions of the review were that underfeeding in the first part of the lactation results in a carryover effect in the range of 35 to $50 \%$ of the immediate effect in the first part of the post-underfeeding period and up to $15 \%$ of the total lactation production. The immediate milk response from increased feeding level ranged from 1.87 to $3.44 \mathrm{~kg}$ of milk/d and the mean carryover response ranged from 0.67 to $1.30 \mathrm{~kg}$ of milk/d, with the highest 
responses found when previous feeding levels were the lowest. These results showed that the production gains of high feeding levels were smaller than the production losses of underfeeding due to the law of diminishing returns (Broster and Broster, 1984). The results for live weight changes showed a carryover effect of the opposite trend to that shown by milk yield. This means that, by imposing a low feeding level to cows in early lactation, they prioritize more nutrients toward live weight gain in later lactation (Broster and Broster, 1984). Since these studies were conducted, notable changes have occurred in dairy management and cow genetics. Several recent studies on the subject have been published. The present paper gathers this newer knowledge to quantify the carryover effects of early lactation feeding on total lactation performance. All selected studies practiced group feeding of cows in contrast to older studies where restricted amounts or forage was allocated individually to the animals (neck-tied cows). The cows in the selected studies were pasture fed, paddocks fed, or indoor fed, and to gain a sufficient number of studies no separate analysis was made for these 3 systems of forage feeding. Studies with individually restricted forage feeding, however, were rejected for the purpose of this review.

\section{MATERIALS AND METHODS}

The first selection criterion for articles was year of publication, and we decided only to use articles published in 1980 and later. Feeding, pasture, animal management, and cow genetics have changed over years; therefore, the results obtained in older studies might not be relevant in modern dairy production. Another criterion was the study design, which should include a change in energy feeding level during one lactation. Several studies investigated the carryover effect of feeding in one lactation on production in subsequent lactations, but these studies were not relevant in the present article. The production parameters required in the articles included, at minimum, milk production and feeding level during the treatment period and during the carryover period together with the length of the treatment period and the carryover period. After this selection, 9 papers fulfilled the criteria and were included in the present review. Eight out of the 9 papers were from pasture-based systems. Most studies used Holstein-Friesian cows, but other breeds are also represented.

The immediate effect of feeding level is the difference in production between groups of cows on different feeding levels during the treatment period. The carryover effect on milk yield was calculated as the difference in production between 2 groups of cows on the same feeding level that were previously fed different levels of energy. The length of the carryover period differed markedly between articles. Thus, the difference in production was divided by the number of days in the carryover period (i.e., the carryover effect is presented as production response per day).

\section{RESULTS}

Kennedy et al. (2007) studied the influence of daily pasture allowance and supplementation level during 11 wk for 66 Holstein-Friesian dairy cows in early lactation on animal performance throughout lactation. Treatments were imposed when cows were, on average, 2 to $11 \mathrm{wk}$ in milk and consisted of 3 pasture allowance levels $(13,16$, and $19 \mathrm{~kg}$ of $\mathrm{DM} / \mathrm{cow},>4 \mathrm{~cm})$ and 2 concentrate supplementation levels (0 and $4 \mathrm{~kg}$ of DM/ cow per day). Concentrate supplementation increased production of milk $(4.1 \mathrm{~kg} / \mathrm{cow}$ per day) and solidscorrected milk (SCM; $2.8 \mathrm{~kg} /$ cow per day). In addition, supplemented animals gained $0.23 \mathrm{~kg} / \mathrm{cow}$ per day $(P<0.01)$ more than unsupplemented cows. The authors found a significant $(P<0.001)$ carryover effect of concentrate supplementation on milk $(+2.6 \mathrm{~kg} / \mathrm{cow}$ per day $), \mathrm{SCM}(+2.3 \mathrm{~kg} / \mathrm{cow}$ per day $)$, milk fat $(+91.1$ $\mathrm{g} / \mathrm{d})$, and protein $(+71.9 \mathrm{~g} / \mathrm{d})$ yields during a subsequent 4 -wk period following the treatment period. On the other hand, no carryover effect of pasture level was noted in the treatment period on any milk production variables. Neither did Kennedy et al. (2007) find any effect of initial concentrate supplementation on BW $4 \mathrm{wk}$ after the treatment period. The cumulative concentrate input for supplemented animals was $382 \mathrm{~kg}$ of DM/ cow. The total lactation milk yield of cows offered concentrate in the treatment period was increased $(+432$ $\mathrm{kg} /$ cow per year; $P<0.01)$ compared with cows that received no concentrate throughout the year $(5,168 \mathrm{~kg} /$ cow per year). The mean milk production response during the treatment period was $1.1 \mathrm{~kg}$ of milk/ $\mathrm{kg}$ of concentrate DM offered and over the total lactation the response was $1.13 \mathrm{~kg}$ of milk/ $\mathrm{kg}$ of concentrate DM.

In a similar study (McEvoy et al., 2008), the effects of concentrate and pasture allowance level were studied to estimate the optimal concentrate level for dairy cows in early lactation and to investigate the carryover effects of the treatments in early lactation on milk output and BW. The experiment included 72 Holstein-Friesian assigned to 1 of 6 grazing treatments for a treatment period of $11 \mathrm{wk}$. Treatments consisted of 2 pasture allowance levels (13 or $17 \mathrm{~kg}$ of herbage $\mathrm{DM} /$ cow per day, $>4 \mathrm{~cm})$ and 3 levels of concentrate $(0,3$, or $6 \mathrm{~kg}$ of $\mathrm{DM} /$ cow per day). Increased herbage intake significantly increased milk (1.85 kg/cow per day), SCM, and 
Table 1. Location, experimental design, and effect of treatment in the 9 studies compared in this review

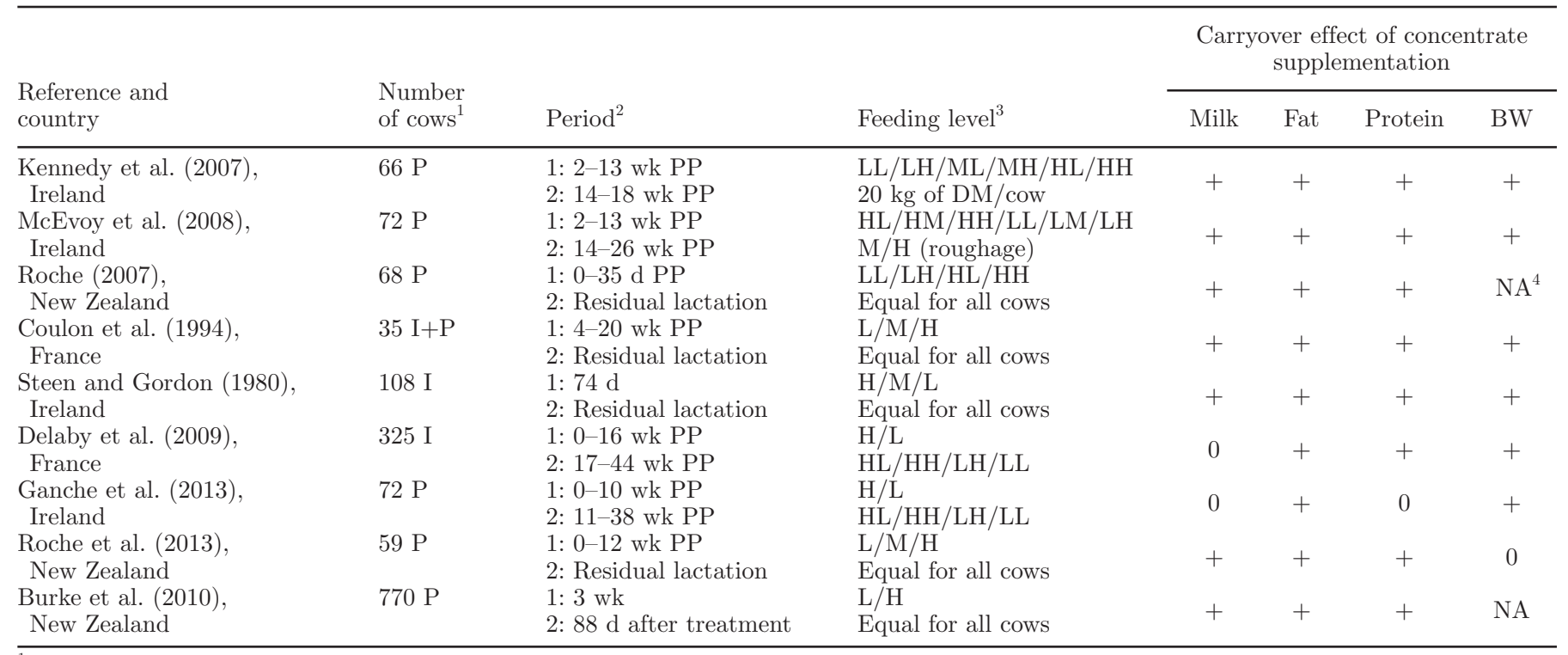

${ }^{1}$ Letters indicate system; $\mathrm{P}=$ pasture, $\mathrm{I}=$ indoor.

${ }^{2} \mathrm{PP}=$ postpartum.

${ }^{3}$ Feeding level: $\mathrm{H}=$ high, $\mathrm{M}=$ medium, $\mathrm{L}=$ low.

${ }^{4}$ Information not available.

BW during the treatment period. During this time, a linear response in milk and SCM yield to concentrate supplementation was also observed. Mean milk yield of unsupplemented animals was $26.8 \mathrm{~kg} /$ cow per day; offering concentrate increased mean milk yield by 1.8 (3 kg of concentrate) and $4.3 \mathrm{~kg} / \mathrm{cow}$ per day (6 kg of concentrate). Solids-corrected milk increased by 1.8 (3 $\mathrm{kg}$ of concentrate) and $3.7 \mathrm{~kg} / \mathrm{cow}$ per day $(6 \mathrm{~kg}$ of concentrate) compared with unsupplemented cows (24.2 $\mathrm{kg} /$ cow per day). The results showed significant $(P<$ $0.01)$ carryover effect of concentrate supplementation in early lactation on milk yield, SCM, milk fat, milk protein, and $\mathrm{BW}$ in a subsequent 12-wk period following the treatment period (Table 1). Previous herbage intake continued to have a significant carryover effect on milk protein $(P<0.05)$ and end-point BCS $(P<$ 0.001).

Steen and Gordon (1980) studied the effect of level of energy supply in early lactation on total lactation performance in 180 multiparous British Friesian cows over 2 yr. At calving (January and February), cows were randomly allocated to 1 of 6 treatments, which consisted of 3 levels of concentrate fed in 1 of 2 systems. The systems were either a high input for $28 \mathrm{~d}$ after calving followed by a low feeding level (high/low system) or a uniform daily feed allowance (uniform system). For $74 \mathrm{~d}$ postpartum, on average, cows were housed indoors and fed grass silage ad libitum. After that period, cows were turned to pasture and concentrate feeding was eliminated after $14 \mathrm{~d}$ at pasture. Differences in milk yield between cows on the high and low feeding levels was reduced after the treatment period but remained significant for $3 \mathrm{wk}$. Some difference persisted, however, throughout the lactation and equated a total cumulative production of $270 \mathrm{~kg}$ of milk. This was equivalent to a carryover response of $0.97 \mathrm{~kg}$ of milk $/ \mathrm{kg}$ of concentrate or 1.2 times the direct effect. Differences in live weight due to concentrate feeding were significant during the first $4 \mathrm{wk}$ after the treatment period and were completely eliminated after 18 wk.

To obtain a more precise estimate of the economic impact of supplemental feeding, Roche et al. (2013) quantified the carryover effect of early lactation supplementation on milk production. Fifty-nine multiparous Holstein-Friesian dairy cows were randomly assigned to 0,3 , or $6 \mathrm{~kg}$ of $\mathrm{DM} / \mathrm{d}$ of concentrates in addition to a generous allowance of spring pasture $(>45 \mathrm{~kg}$ of DM/cow per day). Treatments were imposed for the first $12 \mathrm{wk}$ of lactation, after which concentrate supplementation ceased. During the treatment period, milk production increased by $1.19 \mathrm{~kg} / \mathrm{kg}$ of DM of concentrate offered. Milk and milk component yields remained greater for 3 wk after supplementation had stopped. During this 3 -wk period, cows that previously received 3 and $6 \mathrm{~kg}$ of DM of concentrate per day produced an additional 2.3 and $4.5 \mathrm{~kg}$ of milk/d, 0.10 and $0.14 \mathrm{~kg}$ of milk fat $/ \mathrm{d}$, 
and 0.10 and $0.14 \mathrm{~kg}$ of milk protein/d, respectively, relative to unsupplemented cows $(27.9 \mathrm{~kg}$ of milk, 1.14 $\mathrm{kg}$ of milk fat, and $0.95 \mathrm{~kg}$ of milk protein per day). The carryover milk yield response equated to $0.19 \mathrm{~kg}$ of milk $/ \mathrm{kg}$ of concentrate DM over the $3 \mathrm{wk}$. Roche et al. (2013) concluded that a positive adjustment factor for milk yield variables, milk fat, and protein should be built into management advice for dairy producers to account for the carryover effects.

Over 5 yr, Delaby et al. (2009) studied the direct and carryover effects of 4 feeding strategies on total lactation milk production of Holstein and Normande dairy cows. Each year before calving, 72 cows were assigned to 1 of the 4 feeding strategies, Hh, Hl, Lh, and Ll. The first feeding strategy was applied during 4 mo in the winter (from calving to turn-out) included 2 TMR: maize silage $(14.4 \mathrm{~kg} / \mathrm{cow}$ per day) with $30 \%$ concentrate $(\mathrm{H})$ or grass silage $(13.9 \mathrm{~kg} / \mathrm{cow}$ per day $)$ with $15 \%$ concentrate $(\mathrm{L})$. During the entire grazing season, cows received either 0 (l) or $4 \mathrm{~kg}$ (h) of concentrate and similar amounts of grass. Because grass allowance to the low grazing strategy was significantly lower $(-9$ $\mathrm{kg}$ /cow per day), the postgrazing sward height was lowest in the low allowance group $(5.5$ vs. $6 \mathrm{~cm})$. In the winter period, the groups $\mathrm{Hh}, \mathrm{Hl}, \mathrm{Lh}$, and $\mathrm{Ll}$ consumed 1,407, 773, 1,026, and $392 \mathrm{~kg}$ of concentrate DM and produced $7,567,6,720,7,015$, and $6,238 \mathrm{~kg}$ of milk, respectively, over the total lactation. The high level of feeding applied during the winter period increased the immediate milk production $(+4.2 \mathrm{~kg} /$ cow per day). Winter treatment had no effect on milk yield during the grazing period (carryover period). At pasture, however, the milk fat $(+0.90 \mathrm{~g} / \mathrm{kg})$ and milk protein $(+0.5$ $\mathrm{g} / \mathrm{kg}$ ) content in the milk was significantly higher in cows that received the high feeding level during winter. Cows assigned to the low feeding level during winter gained significantly more live weight during the grazing period $(+0.31 \mathrm{~kg} / \mathrm{d})$ compared with cows on the winter high treatment $(+0.21 \mathrm{~kg} / \mathrm{d})$, but at the end of the grazing season these cows weighed less than cows fed a high level during winter. The study showed that feeding strategy had a marked influence on the shape of the lactation curves. Even though the lactation curves were parallel in the first month of lactation for cows fed high or low level, the lactation curves resulting from the low-high treatment was flatter. Thus, cows on the low feeding level during winter and high feeding level later in lactation (low-high cows) made use of the additional energy input for both milk production and recovery of body condition.

To examine the effect of level of concentrate offered to cows in wk 4 to 20 of lactation on total lactation performance, Coulon et al. (1994) performed an ex- periment with 35 primiparous cows fed 3 different concentrate levels (high, medium, and low) and 2 feeding patterns (standard, flat). At the end of pregnancy and in the first $3 \mathrm{wk}$ of lactation cows were fed the same diet. From the fourth week of lactation through the following $16 \mathrm{wk}$, all cows received $10 \mathrm{~kg}$ of DM roughage per day and concentrates adjusted to production level. It was considered that the roughages covered the maintenance requirements for energy and protein and requirements to produce 3 (high), 7 (medium), or 11 $\mathrm{kg}$ (low) of milk. The concentrate was distributed at a level of $0.4 \mathrm{~kg}$ for each $\mathrm{kg}$ of milk over these production levels. These feeding levels resulted in an energy balance (units for lactation) between 0 (high) and -0.8 (low). As expected, cows on the high energy level had the highest milk yield and milk protein concentration in milk. Following the experimental period, cows were turned out on pasture and fed equal pasture allowance levels for the rest of the lactation. At pasture, the differences in production response between treatment groups decreased. In the highest-producing animals however, a difference in milk production of $1.4 \mathrm{~kg}$ of milk per day was maintained until the end of lactation between the highest and lowest supplemented groups. Coulon et al. (1994) concluded that severe underfeeding in early lactation has a marked effect on total lactation performance.

Ganche et al. (2013) examined the carryover effect of early lactation postgrazing sward heights, one driver of feed restriction, on subsequent dairy cow performance. In total, 72 spring-calving Holstein-Friesian cows were randomly assigned to 1 of 2 grazing treatments (sward heights 2.7 or $3.5 \mathrm{~cm}$ ) during 10 wk after calving [period 1 (P1)]. Before the initiation of period 2 (P2), animals were rerandomized within their P1 treatments and assigned to graze to either 3.5 or $4.5 \mathrm{~cm}$ sward height for the next $27 \mathrm{wk}$. On average, cows on the low level in P1 tended to have a greater grass DMI throughout $\mathrm{P} 2(+0.8 \mathrm{~kg}$ of $\mathrm{DM} / \mathrm{cow})$ than cows fed on a higher level during P1 (14.1 kg of DM/cow), but no significant effect of P1 treatment on milk yield during P2 or on total lactation cumulative milk production was noted. Ganche et al. (2013) suggested a reactivation of mammary secretory alveoli as a possible explanation for the recovery of milk production in P2 for restricted animals during P1. Some carryover effects of P1 treatment were observed for milk fat and protein concentrations in later lactation (i.e., the loss of milk solids during P1 was not recovered by the end of the lactation).

The effect of feed restriction in early lactation on subsequent milk production was studied by Roche (2007). Sixty-eight cows calving in July (southern hemisphere) were randomly allocated to 2 precalving pasture allow- 
ances for 4 wk precalving (high $=11.9 \mathrm{~kg}$ of DM; low $=4.8 \mathrm{~kg}$ of $\mathrm{DM}$ ), equivalent to 131 and $51 \%$ of energy requirements for the high and low treatment groups, respectively. At calving, cows within each precalving treatment group were randomly allocated to 1 of 2 levels of feeding (high $=13.5 \mathrm{~kg}$ of DM; low $=8.6 \mathrm{~kg}$ of DM) for 5 wk postcalving. Following the treatment period, all cows were allowed equal amounts of feed (pasture). The results showed that restriction of cows for 5 wk postcalving reduced $(P<0.01)$ milk yield $(205$ $\mathrm{kg}$ of $\mathrm{SCM})$, milk fat $(7.0 \mathrm{~kg})$, and milk protein $(5.0 \mathrm{~kg})$ yields for a further $10 \mathrm{wk}$ postrestriction, after which differences ceased.

The effect of acute feed restriction was studied by Burke et al. (2010). The main focus was put on reproductive performance of the cows, but ECM yield was also measured during the treatment period and a subsequent 88-d period. The study involved 770 mixedage cows randomly allocated to 1 of 2 treatments: high versus low pasture allowance (HPA vs. LPA). All cows were managed similarly before and after the 14-d treatment period, which began at the first day of the mating period. In the first treatment week, pasture allowances were incrementally reduced by $2.4 \mathrm{~kg}$ of $\mathrm{DM} /$ cow per day for LPA cows and incrementally increased by 0.8 $\mathrm{kg}$ of DM/cow per day for HPA cows. During the subsequent $2 \mathrm{wk}$, cows received 8.0 and $14.3 \mathrm{~kg}$ of DM/cow per day in groups LPA and HPA, respectively. Feeding level immediately affected milk production, as the LPA cows produced $30 \%$ less SCM during the 14-d treatment period compared with HPA cows. In addition, a subsequent effect of feeding was apparent and LPA cows produced 14 and $8 \%$ less milk at 10 and $25 \mathrm{~d}$ after the treatment period, respectively. These treatment differences were still apparent $40 \mathrm{~d}$ after treatment but not after $88 \mathrm{~d}$.

\section{DISCUSSION}

Little consensus exists in the literature on the existence or absence of carryover effects of early lactation feeding on milk production and weight change. In some trials (Steen and Gordon, 1980; Kennedy et al., 2007; Roche et al., 2013) the authors described a significant carryover effect on milk production, even though its persistency was rather limited (1 to $2 \mathrm{mo}$ ). Other trials found no carryover effects of early lactation feeding on milk yield (Delaby et al., 2009; Ganche et al., 2013).

The inconsistency in findings regarding carryover effects of early lactation feeding on total lactation milk yield and end lactation BW may be due to variations in energy intake, timing of feed changes, amplitude of changes, and duration of both the treatment and car- ryover periods. In the early studies reviewed by Broster and Broster (1984), the carryover effects of early lactation feeding were greater and of longer durations than the carryover effects found in newer literature. The reason for the disagreement between the studies could be the differences in the duration of feed restriction, precalving feeding level, and especially the feeding level following the feed restriction period. A probable explanation is that cows were offered individually a fixed amount of roughage in the early studies, whereas the most common feeding strategy in later studies is group roughage feeding. When cows feed in groups, they will to some extend be able to compensate for a lower concentrate supplementation by adjusting the roughage intake (Nielsen et al., 2007).

\section{Quantification of Carryover Effects}

Out of the 9 studies reviewed, 7 found a significant carryover effect of previous feeding on subsequent milk production (Table 2 ). In the 2 studies in which no significant carryover effect was shown (Delaby et al., 2009; Ganche et al., 2013), the length of the post-treatment period was considerably longer than in the other studies and that might be the reason for the lack of a significant carryover effect. This explanation is supported by the fact that the duration of the carryover effect was relatively short in the 7 studies where the effect was reported on a time scale. In these studies the immediate effect of feeding level (i.e., the difference between treatment cows at the lowest and the highest feeding level) ranged between 2.5 and $7.1 \mathrm{~kg}$ of milk/cow per day. The carryover periods ranged from 3 to 12 wk and the difference in milk yield between cows in the carryover periods ranged between 1.5 and $4.5 \mathrm{~kg}$ of milk/cow per day. When calculated as a percentage of the immediate effect, the carryover effect ranged from 22 to $63 \%$. The relation between the length and magnitude of the carryover effect is inversely proportional (Figure 1); that is, the size of the carryover effect decreases with time after the treatment period (in fact this is a dilution of the carryover response).

The reviewed studies indicate that the duration of the treatment period influences the duration of the carryover period. For instance, Burke et al. (2010) investigated the effect of feed restriction for $3 \mathrm{wk}$ and found that the difference in milk production between cows on high and low feeding levels ceased 5 to 6 wk after the treatment period. In a similar study (Roche, 2007), cows were restricted for $5 \mathrm{wk}$ and they had a lower milk production than their nonrestricted herdmates for 10 wk. Therefore, it seems that at a similar level of feed restriction, the longer the restriction was imposed for, the longer the carryover effect. 


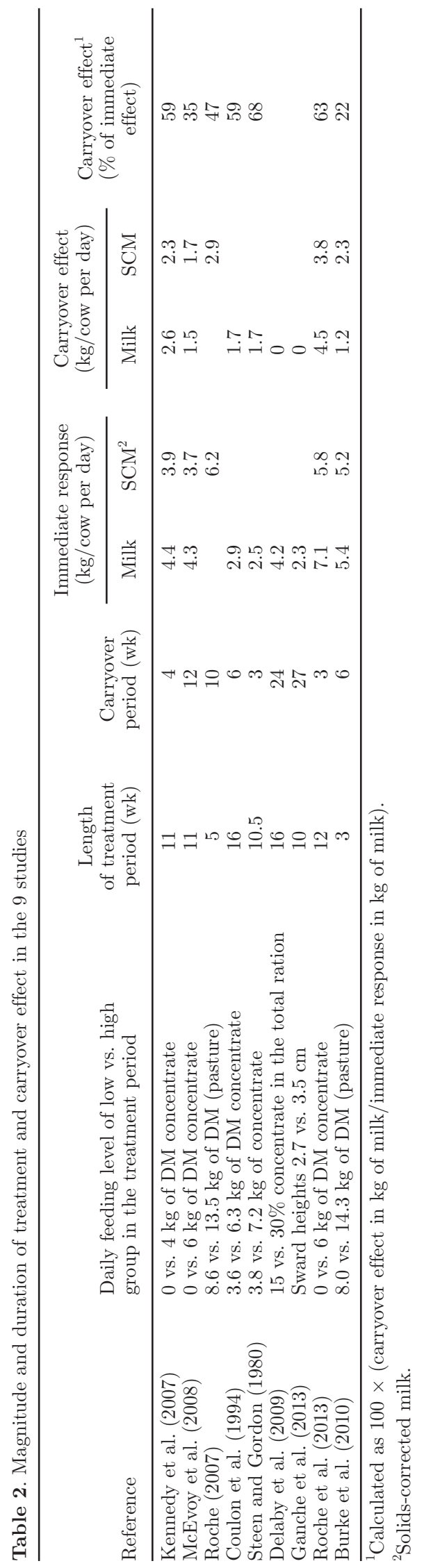

\section{Milk Yield Response in Relation to Timing of Feed Changes}

Milk yield response to changes in feed energy level seems to be affected by stage of lactation (i.e., milk yield response to concentrate introduction diminish as stage of lactation increases; Broster, 1972). Also, the negative effect of reducing energy supply on milk production is minimized the earlier it is introduced as suggested by Bossen and Weisbjerg (2009) and Bossen et al. (2009) in a Danish study on effects of feeding cows according to individual live weight changes. In a 4-yr trial, 299 cows were allocated to 1 of 3 feeding strategies. Cows were either allowed a medium-energy ration during the whole lactation or a high-energy ration during early lactation, which was reduced to a low-energy ration either early or late in lactation. The early and late stages of lactation were defined as a live weight gain after live weight minimum at 15 and $35 \mathrm{~kg}$, respectively, for large breed cows and at 11 and $25 \mathrm{~kg}$, respectively, for Jersey cows. The results suggested that when energy supply was decreased in early lactation, cows obtained a higher total lactation SCM yield due to a higher yield persistency compared with cows offered the high energy supply for a longer time period in early lactation. Bossen and Weisbjerg (2009) and Bossen et al. (2009) concluded that the early feed reduction is followed by a reentry to body reserve mobilization metabolism, whereas the late feed reduction results in lower milk yield persistency and a continued increase in live weight gain. Thus, it is suggested that transition from mobilization to deposition of body reserves is a reversible process, but only as long as the cows are not fully adapted to deposition metabolism. The influence of lactation stage on partitioning of nutrients between milk and body reserves is further supported by Kirkland and Gordon (2001), who used indirect calorimetry to investigate the effect of lactation stage on responses to changes in energy supply. Their study included 20 cows in 3 different stages of lactation (mean DIM = 77, 225, and 423, respectively). Kirkland and Gordon (2001) found that a change in ME intake in early lactation cows resulted in higher milk yield and protein response than in late-lactation cows. We, therefore, concluded that the carryover effect of the feeding level in early lactation on milk production in late lactation is less pronounced if the change is made at a reasonable early time in the lactation.

\section{Recovery of Milk Production after Feed Restriction}

Some studies support the hypothesis that milk production can recover to some degree after a period of feed restriction. For instance, in the study of Roche 


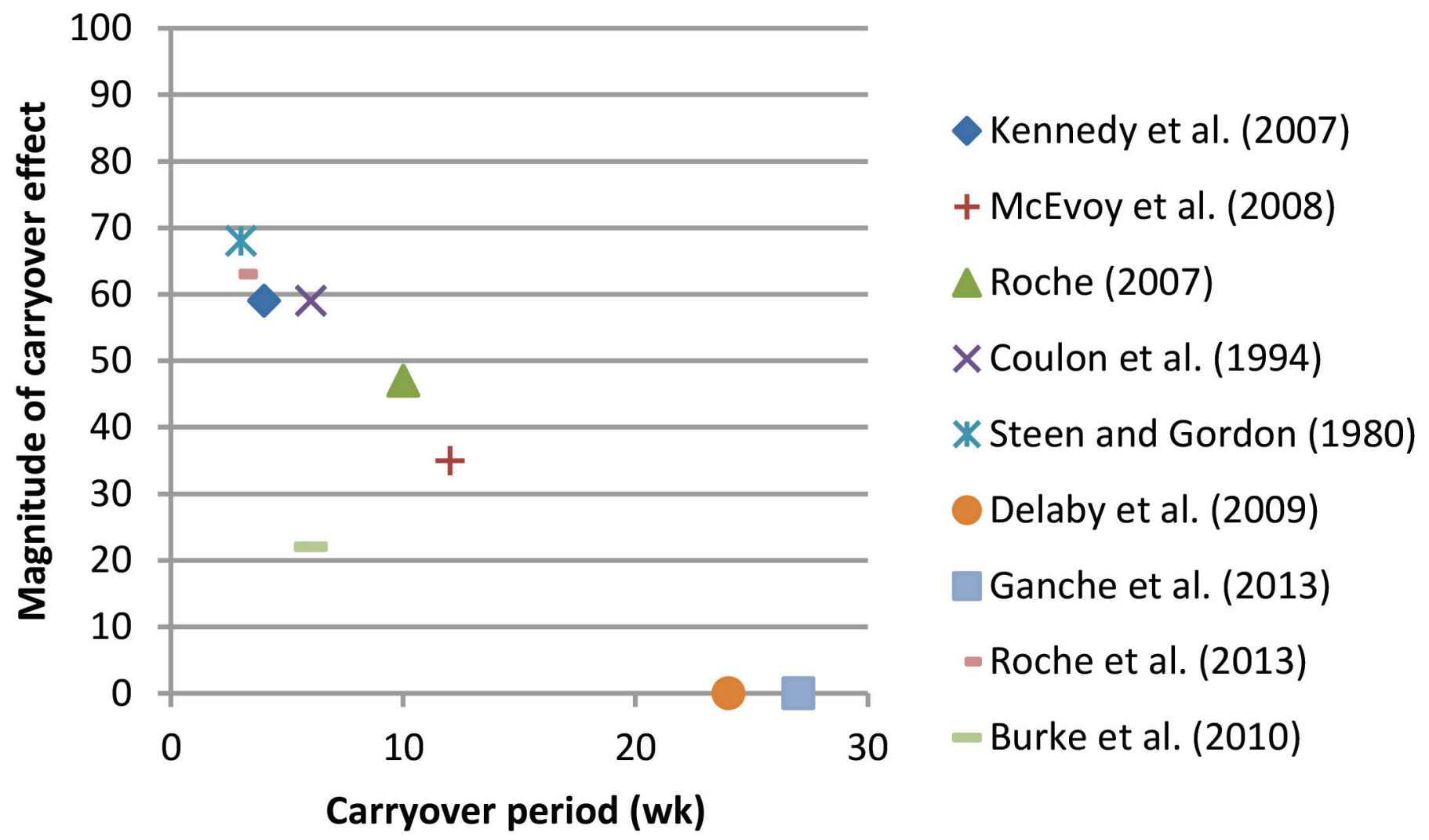

Figure 1. The relation between the magnitude and duration of the carryover effect in the 9 studies. The magnitude of the carryover effect is calculated as a percentage of the immediate effect [(100/immediate effect) $\times$ carryover effect]. Color version available online.

(2007), severe energy restriction during the first $5 \mathrm{wk}$ after calving caused a reduced milk production in the following $10 \mathrm{wk}$ corresponding to $47 \%$ of the immediate lost production; after that time the difference in milk production between treatment groups ceased. Roche (2007) clearly shows that even after a period of severe undernutrition cows are able to increase milk production when the energy level is raised. Other studies show no or weak carryover effects of early lactation feeding, though (Delaby et al., 2009; Ganche et al., 2013). This might be due to the increase in milk production after the treatment period (the carryover effect), which only lasts a limited time, and the examined carryover period may be different from the time period for which the carryover effect is significant. The studies of Delaby et al. (2009) and Ganche et al. (2013) examined a carryover period equal to the remainder of the lactation (and found no carryover effect), whereas if they had stopped the carryover period (end of all measures) at wk 4 or 5 after the end of early lactation treatment this carryover effect would have been significant, as illustrated by the lactation curves in both articles.

In most studies conducted 30 to 50 yr ago, early lactation feed restriction led to a lower milk yield for the remainder lactation (Van Soest, 1982). The magnitude of these carryover responses was 2 to 4 times the direct effect obtained in autumn-calving cows offered restricted quantities of roughages (Steen and Gordon, 1980). In many of these early studies the carryover effects were often demonstrated in trials where the low feeding level in fact were underfeeding compared with normal feeding, whereas this was not always the case in the recent studies and that might be an explanation for the different results obtained.

\section{Reasons for the Carryover Effect}

Reduction of nutritive inputs to cows in early lactation causes reduced milk yield and increased mobilization of body reserves (Friggens et al., 1995). According to Ganche et al. (2013), cows on a low nutrient level in early lactation had increased milk synthesis when feeding was increased and at the same time cows gained more BW in later lactation due to a significantly higher grass DMI compared with cows on high nutrient level in early lactation. By contrast, feeding a high-energy ration in early lactation slightly improves the milk production and energy balance and the duration of body 
reserve mobilization is reduced accordingly (Delaby et al., 2009).

One reason for the carryover effect of feeding on milk production may involve an increase in either mammary cell number or secretory cell activity (Nørgaard et al., 2005). Another plausible explanation could be an increased feed intake in cows that were previously supplemented because of increased hunger associated with their greater milk production when the supplements were removed (Roche, 2007). A third explanation could be that the carryover effect on milk production is related to a mobilization of body reserves (Kennedy et al., 2007). The temporary carryover effect is likely a result of more factors, and further work is needed to fully understand the physiology, but it seems that the nutrient partition between milk yield and body reserves mobilization plays a major role.

\section{Future Investigations}

Most studies investigating the effect of concentrate supplementation in early lactation on subsequent lactation performance are conducted in countries where seasonal calving and pasture-based dairy systems are common (e.g., Ireland, New Zealand, and specific parts of France). However, the carryover effect of feeding level on subsequent milk yield and body condition is also important in nongrazing systems for estimation of the economic optimal feeding level. To obtain useful information on the duration and magnitude of the carryover effect, studies should be designed so that milk yield and BW are measured frequently over a sufficiently long time period. Knowledge on animal energy status might improve our understanding of the physiology behind the carryover phenomenon.

\section{CONCLUSIONS}

Recent studies have confirmed the hypothesis that feeding in early lactation influences production in later lactation. The magnitude and duration of the carryover effects reviewed in this paper were lower than those found in earlier studies (before 1980). In many of the earlier studies the carryover effects were often demonstrated in trials where the low feeding levels were underfeeding compared with normal feeding, whereas this was not always the case in the recent studies. In addition to the post-treatment feeding level, the magnitude and duration of carryover effects are closely related to the immediate effects of feeding level, which is also influenced by duration, amplitude or magnitude, and timing of treatment. Results from the present review show carryover periods ranging from 3 to 12 wk and a difference in milk yield between cows in the carryover periods ranging between 1.5 and $4.5 \mathrm{~kg}$ of milk/cow per day. The milk yield of restricted animals earlier in lactation can be recovered once they are offered adequate nutrient supply (degree of recovery depends on stage of lactation). The magnitude and duration of the carryover effect are also related to the immediate effect of feeding level as well as the average size of the carryover effect, which is related to the duration of the examined carryover period.

\section{ACKNOWLEDGMENTS}

This work was supported by a grant (GUDP) from the Ministry of Environment and Food of Denmark, SEGES Cattle, and from the Swedish Farmer's Foundation for Agricultural Research.

\section{REFERENCES}

Bossen, D., and M. R. Weisbjerg. 2009. Allocation of feed based on individual dairy cow live weight changes: II: Effect on milk production. Livest. Sci. 126:273-285.

Bossen, D., M. R. Weisbjerg, L. Munksgaard, and S. Højsgaard. 2009. Allocation of feed based on individual dairy cow live weight changes: I: Feed intake and live weight changes during lactation. Livest. Sci. 126:252-272.

Broster, W. H. 1972. Effect on milk yield of the cow of the level of feeding during lactation. J. Dairy Sci. 34:23.

Broster, W. H., and V. J. Broster. 1984. Reviews of the progress of Dairy Science: Long term effects of plane of nutrition on the performance of the dairy cow. J. Dairy Res. 51:149-196.

Broster, W. H., V. J. Broster, and A. J. Clements. 1993. Feed utilization by the dairy cow over multiple lactations: A review. Livest. Prod. Sci. 34:1-21.

Burke, C. R., Y. J. Williams, L. Hofmann, J. K. Kay, C. V. C. Phyn, and S. Meier. 2010. Effects of an acute feed restriction at the onset of the seasonal breeding period on reproductive performance and milk production in pasture-grazed dairy cows. J. Dairy Sci. 93:1116-1125.

Coulon, J. B., P. D'Hour, J. P. Garel, and M. Petit. 1994. Level and pattern of winter concentrate allocation in dairy cows: Results in first lactation cows. Anim. Sci. 59:11-20.

Coulon, J. B., and B. Rémond. 1991. Variations in milk output and milk protein content in response to the level of energy supply to the dairy cow: A review. Livest. Prod. Sci. 29:31-47.

Delaby, L., P. Faverdin, G. Michel, C. Disenhaus, and J. L. Peyraud. 2009. Effect of different feeding strategies on lactation performance of Holstein and Normande dairy cows. Animal 3:891-905.

FAO. 2012. Price Volatility from a Global Perspective. Food and Agriculture Organization of the United Nations, Rome, Italy.

Friggens, N., G. C. Emmans, S. Robertson, D. G. Chamberlain, C. T. Whittemore, and J. D. Oldham. 1995. The lactational responses of dairy cows to amount of feed and to the source of carbohydrate energy. J. Dairy Sci. 78:1734-1744.

Ganche, E., L. Delaby, M. O’Donovan, T. M. Boland, and E. Kennedy. 2013. Direct and carryover effect of post-grazing sward height on total lactation dairy cow performance. Animal 7:1390-1400.

Holcomb, C. S., H. H. Van Horn, H. H. Head, M. B. Hall, and C. J. Wilcox. 2001. Effects of prepartum dry matter intake and forage percentage on postpartum performance of lactating dairy cows. J. Dairy Sci. 84:2051-2058.

Holter, J. B., M. J. Slotnick, H. H. Hayes, C. K. Bozak, W. E. Urban Jr., and M. L. McGilliard. 1990. Effect of prepartum dietary en- 
ergy on condition score, postpartum energy, nitrogen partitions, and lactation production responses. J. Dairy Sci. 73:3502-3511.

Kennedy, E., M. O'Donovan, F. P. O'Mara, J. P. Murphy, and L. Delaby. 2007. The effect of early-lactation feeding strategy on the lactation performance of spring-calving dairy cows. J. Dairy Sci. 90:3060-3070.

Kirkland, R. M., and F. J. Gordon. 2001. The effects of stage of lactation on the partitioning of, and responses to changes in, metabolisable energy intake in lactating dairy cows. Livest. Prod. Sci. 72:213-224.

McEvoy, M., E. Kennedy, J. P. Murphy, T. M. Boland, L. Delaby, and M. O'Donovan. 2008. The effect of herbage allowance and concentrate supplementation on milk production performance and dry matter intake of spring-calving dairy cows in early lactation. J. Dairy Sci. 91:1258-1269.

Nielsen, N. I., N. C. Friggens, T. Larsen, J. B. Andersen, M. O. Nielsen, and K. L. Ingvartsen. 2007. Effect of changes in diet energy density on feed intake, milk yield and metabolic parameters in dairy cows in early lactation. Animal 1:335-346.

Nørgaard, J., A. Sørensen, M. T. Sørensen, J. B. Andersen, and K. Sejrsen. 2005. Mammary cell turnover and enzyme activity in dairy cows: Effects of milking frequency and diet energy density. J. Dairy Sci. 88:975-982.

Roche, J. R. 2007. Milk production responses to pre- and postcalving dry matter intake in grazing dairy cows. Livest. Sci. 110:12-24.

Roche, J. R., J. K. Kay, A. G. Rius, T. M. Grala, A. J. Sheahan, H. M. White, and C. V. C. Phyn. 2013. Short communication: Immediate and deferred milk production responses to concentrate supplements in cows grazing fresh pasture. J. Dairy Sci. 96:2544-2550.

Sejrsen, K., and S. Purup. 1997. Influence of prepubertal feeding level on milk yield potential of dairy heifers: A review. J. Anim. Sci. 75:828-835.

Steen, R. W. J., and F. J. Gordon. 1980. The effect of level and system of concentrate allocation to January/February calving cows on total lactation performance. Anim. Sci. 30:39-51.

Van Soest, P. J. 1982. Nutritional Ecology of the Ruminant. Cornell University Press, Ithaca, NY.

Wiktorsson, H. 1971. Studies on the effects of different levels of nutrition to dairy cows. Swed. J. Agric. Res. 1:20. 